\title{
Relation Between Cardiovascular Disease Risk Factors and Common Carotid Artery Intima Media Thickness
}

\author{
Kardiyovasküler Hastallk Risk Faktörleri ve Karotis Arter Intima Media Kalınlığı Arasındaki Ilișki
}

\author{
Kadihan Yalçın Șafak, Mehmet Akçiçek \\ Department of Radiology, Dr. Lütfü Kirdar Training and Research Hospital, İstanbul, Turkey
}

\begin{abstract}
AIM: To determine the effects of age, sex, smoking, hypertension, diabetes mellitus, hyperlipidemia, history of coronary artery disease and cerebrovascular disease on carotid intima media thickness.

METHODS: Patients $(N=222)$ undergoing Color Doppler Ultrasound examination of the extra cranial carotid arteries for any reason in a four-month-period were prospectively investigated. Posterior wall intima media thickness on 1-1.5 cm distal part of both common carotid arteries was measured three times for each patient. The mean values of measurements of right and left common carotid arteries, the presence of atherosclerotic plaque and vessel stenosis $\geq 15 \%$ were recorded. The effects of age, sex, smoking, hypertension, diabetes mellitus, hyperlipidemia, coronary artery disease, and cerebrovascular disease on common carotid arteries intima media thickness and the relationship between common carotid arteries intima media thickness and plaque existence were investigated.
\end{abstract}

RESULTS: Age, sex, smoking, hypertension, diabetes mellitus, hyperlipidemia, coronary artery disease and cerebrovascular disease individually increased the common carotid arteries intima media thickness according to univariate analysis. All of the parameters but diabetes mellitus were defined as risk factors by using regression analysis. Hypertension followed by hyperlipidemia, coronary artery disease and cerebrovascular disease had more power.

CONCLUSION: Intima media thickness of common carotid arteries is affected by un-modifiable factors such as age and sex and by modifiable factors such as smoking, hypertension, hyperlipidemia, coronary artery disease and cerebrovascular disease.

Key words: cardiovascular diseases; carotid intima-media thickness; demography; Doppler; echocardiography; risk

\section{ÖZET}

AMAÇ: Yaș, cinsiyet, arteriyel hipertansiyon öyküsü, diabetes mellitus, hiperlipidemi, koroner arter ve serebrovasküler hastalık öyküsü ve sigara kullanımının karotis intima media kalınlığı üzerine etkisini belirlemektir.

Uzm. Dr. Kadihan Yalçın Safak, Acıbadem Cad. Eczacı Necip Akar Sok. No: 8, İstanbul, Türkiye Tel.05368863306Email.drkadihan@yahoo.com

Received: 27.08.2013 • Accepted: 17.10.2014
YÖNTEM: Herhangi bir nedenden dolayı kliniğimizde, dört aylık periyotta ekstrakranial karotis arterlere yönelik Renkli Doppler Ultrasonografi incelemesi yapılan olgular $(N=222)$ prospektif olarak değerlendirildi. Her olgunun karotis intima media kalınlığı, her iki ana karotis arterin yaklașık 1-1,5 cm'lik distal bölümünden, yalnızca posterior duvardan, üçer kez ölçüldü. Sağ ve sol ana karotis arterden ölçülen değerlerin ortalaması alınıp kaydedildi. Aterosklerotik plak varlığı kaydedildi. Çap ölçümüne göre $\geq$ \% 15 darlığı olan olgular seçildi. Yaș, cinsiyet, hipertansiyon, diyabet, hiperlipidemi, kardiyovasküler hastalık öyküsü ve sigara kullanımının ana karotis arterin intima media kalınlığı üzerine etkisi ve plak varlığı ile karotis karotis intima media kalınlığı arasındaki ilișki araștırıldı.

BULGULAR: Yaș, cinsiyet, sigara, koroner arter ve serebrovasküler hastalık öyküsü, hiperlipidemi, hipertansiyon ve diabetes mellitus, univariate analizde ana karotis arterin intima media kalınlığı üzerine tek bașlarına etkili risk faktörleri oldukları saptandı. Yapılan regresyon analizi sonucunda diabetes mellitus dıșındaki tüm parametrelerin ana karotis arterin intima media kalınlığı üzerine anlamı etkisi olduğu görüldü. En önemli etkinin hipertansiyondan kaynaklandığı bunu, hiperlipidemi, koroner arter ve serebrovasküler hastalık öyküsü değișkenlerinin takip ettiği saptandı. Plak ve darlık saptanan olguların ana karotis arterin intima media kalınlığı ölçümlerinin, saptanmayanlara göre istatistiksel olarak anlamlı düzeyde yüksek olduğu görüldü.

SONUÇ: Ana karotis arterin intima media kalınlığı; yaș ve cinsiyet gibi değiștirilemeyen risk faktörlerinin yanı sıra, sigara kullanımı, hipertansiyon, hiperlipidemi, koroner arter ve serebrovasküler hastalık gibi değiștirilebilen risk faktörlerinden etkilenir.

Anahtar kelimeler: kardiyovasküler hastalıklar; karotis intima-media kalınlığl; demografi; Doppler; ekokardiyografi; risk

\section{Introduction}

Atherosclerosis is with fatty deposits called atheromatous plaques located on the internal walls of great and moderate arteries. Approximately half of people in the United States of America and in Europe die of diseases related with atherosclerosis ${ }^{1}$.

Increased carotid intima media thickness (IMT) is the earliest morphological sign of atherosclerosis and these 
early changes can be easily detected by B-Mode ultrasonography ${ }^{2,3}$. It is stated that there was a relation between myocardial infarction (MI), stroke and coronary artery disease (CAD) related deaths and carotid IMT ${ }^{4}$. The relation between carotid IMT and traditional cardiovascular risk factors such as age, gender, hypertension (HT), diabetes mellitus (DM), hyperlipidemia and smoking in addition to $\mathrm{CAD}$ and cerebrovascular disease (CVD) was studied previously ${ }^{5-19}$. However, results of these studies are conflicting.

The present study aimed to determine whether the risk factors such as age, gender, HT, DM, hyperlipidemia, CAD, CVD and active smoking influence carotid IMT.

\section{Methods}

The patients undergoing extra cranial carotid artery Color Doppler Ultrasound (CDUS) for various reasons in Lütfü Kırdar Training and Research Hospital Radiology Clinic between May 2012 and August 2012, and between April 2013 and May 2013 were included. All included patients were voluntary to participate and the data were prospectively evaluated. The study was approved by the local ethics committee.

In order to identify the risk factors, the patients were questioned. Age, active smoking habit and history of HT, DM, hyperlipidemia, CAD and CVD were recorded. Exclusion criteria included smokers for less than five years, daily cigarette consumption of less than a half pack, and retrospective smokers quitted.

Patients received antihypertensive therapy or were diagnosed with HT but did not receive any therapy were defined as HT patients. Insulin or oral anti-diabetic drug use or a diagnosis of DM managed with diet therapy was defined as DM. Cholesterol level over $200 \mathrm{mg}$ / $\mathrm{dl}^{1}$ was considered as hyperlipidemia. History of MI, coronary bypass, angina pectoris and use of drugs for CAD were defined as CAD patients. History of stroke and/or transient ischemic attack (TIA) was considered as CVD. The cases that failed to give adequate anamnesis and the cases that underwent endarterectomy of carotid arteries or that had carotid stent were excluded. A total of 222 cases participated.

Ultrasound (US) examination was performed by an experienced radiologist while the patients were in supine position with the head in mild extension and approximately $20^{\circ}$ contralateral cervical rotation. Standard US devices (Logic 9, General Electric Company, USA) and $10 \mathrm{MHz}$ linear transducer were used during examinations.

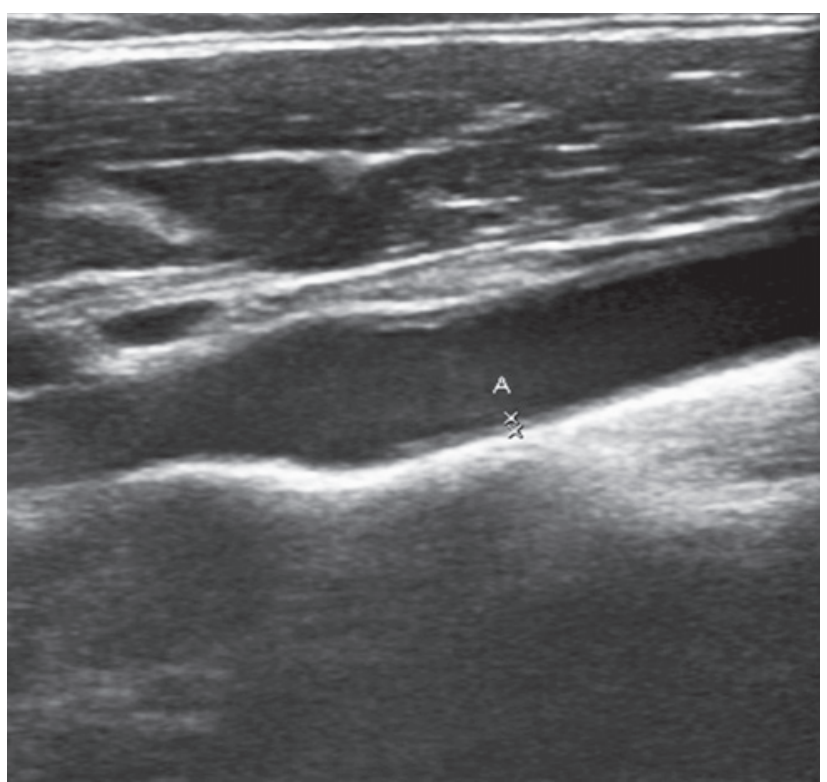

Figure 1. Intima-media thicknesses were measured from the posterior wall at the 1-1.5 cm distal part of Common Carotid Artery.

Common carotid artery (CCA), internal carotid arteries (ICA) and external carotid arteries (ECA) of all cases were evaluated in longitudinal and transverse axes by grey scale, CDUS and Power Doppler Ultrasound (PDUS) techniques. In each case, only posterior wall IMT on the $1-1.5 \mathrm{~cm}$ distal part of both CCAs was measured three times (Figure 1). The characteristic echogenicities of lumen-intima media and mediaadventitia were used for measuring IMT. The values measured from the right and left CCA were separately recorded and their arithmetical mean was calculated. Segments with atherosclerotic plaque were omitted during measurements. An IMT value of $1.5 \mathrm{~mm}$ or higher was considered as plaque ${ }^{20}$. Carotid plaque thickness was evaluated on transverse images (short axis), because it was accepted to demonstrate plaque thickness most correctly ${ }^{21}$. IMT value of $1.5 \mathrm{~mm}$ or more on transverse axis was diagnosed and recorded as plaque. The amount of stenosis in the stenotic area was specified proportionally. For this purpose, the NASCET (North American Symptomatic Carotid Endarterectomy Trail) method recommending was used (proportioning narrowest diameter in longitudinal plane to the normal arterial diameter in the distal part ${ }^{22}$. The cases with a stenosis of $\geq 15 \%$ of the diameter were recorded. Effect of age, gender, HT, DM, hyperlipidemia, CAD, CVD and active smoking on CCA IMT, as well as relation between presence of a plaque and carotid IMT, were investigated. 
NCSS (Number Cruncher Statistical System) 2007\&PASS (Power Analysis and Sample Size) 2008 Statistical Software (Utah, USA) programs were used for statistical analyses. While evaluating study data, in addition to the descriptive statistical methods (mean, standard deviation, median, frequency, ratio, minimum, maximum), for evaluation of quantitative data Student $t$ Test was used as well for paired group comparison of the parameters that showed normal distribution. Relation between the parameters was analyzed by Pearson's correlation analysis. Multivariate Stepwise Linear Regression Analysis was performed to determine the effect of demographic characteristics and risk factors on CCA IMT. The level of significance was evaluated at the levels of $\mathrm{p}<0.01$ and $\mathrm{p}<0.05$.

Table 1. Common carotid artery intima media thickness of 222 patients and the distribution of the risk factors

\begin{tabular}{lcc}
\hline & Mean \pm SD & Min-Max \\
\hline CCA IMT & $0.83 \pm 0.21$ & $0.30-1.40$ \\
\hline Plaque & $\mathrm{N}$ & $\%$ \\
Stenosis & 118 & 53.2 \\
Smoking & 45 & 20.3 \\
CAD & 69 & 31.1 \\
Hyperlipidemia & 18 & 8.1 \\
HT & 71 & 32.0 \\
DM & 111 & 50.0 \\
CVD & 40 & 18.0 \\
\hline
\end{tabular}

CCA: Common carotid artery, IITT: Intima media thickness, CAD: Coronary artery disease, HT: Hypertension, DM: Diabetes Mellitus, CVD: Cerebrovasculary disease.

\section{Results}

A total of 222 cases, 152 (68.5\%) females and 70 (31.5\%) males, participated in the study. The ages of the patients ranged between 15 and 83 years with a mean of $54.31 \pm 13.22$ years. The reason for being referred to our clinic was vertigo in 149 (67.1\%), headache in 22 (9.9\%), paresthesia in the upper extremity in $15(6.7 \%)$, tinnitus in $4(1.8 \%)$, syncope in $4(1.8 \%)$, new-onset stroke in $6(2.7 \%)$, and TIA in $2(0.9 \%)$ of the cases. The remaining $20(9.0 \%)$ cases had been referred to our clinic for a regular control visit.

The CCA IMT values of the cases ranged between $0.30 \mathrm{~mm}$ and $1.40 \mathrm{~mm}$ with a mean of $0.83 \pm 0.21 \mathrm{~mm}$. Plaque and stenosis were detected in $53.2 \%(\mathrm{n}=118)$ and $20.3 \%(n=45)$ of the cases, respectively.

The prevalence of smokers was $31.1 \%(n=69)$; whereas, $8.1 \%(n=18)$ of the cases had CAD, $32.0 \%(n=71)$ had hyperlipidemia, $50 \%(\mathrm{n}=111)$ had HT, $18.0 \%(\mathrm{n}=40)$ had DM, and $11.3 \%(n=25)$ had CVD. Distribution of CCA IMT and the risk factors is demonstrated in Table 1.

Univariate analysis revealed that age, gender, smoking, CAD, hyperlipidemia, HT, DM and CVD were individual risk factors and independently effected CCA IMT. Regression analysis demonstrated that all parameters except DM had significant effect on CCA IMT. It was determined that $\mathrm{HT}$ was the most effective factor followed by hyperlipidemia, CVD and CAD. Whilst the effects of CAD and smoking were found to be significant at the level of $\mathrm{p}<0.05$, age, male gender, hyperlipidemia, CVD and HT were found to be effective at the level of $p<0.01$. Relation of demographic characteristics and risk factors with CCA IMT is demonstrated in Table 2. The mean CCA IMT increased with

Table 2. Relation between some demographic characteristics and common carotid artery intima media thickness

\begin{tabular}{|c|c|c|c|c|}
\hline \multirow[b]{2}{*}{ Model } & \multirow{2}{*}{$\frac{\text { Extra-Standard coefficients }}{\text { B }}$} & \multirow[b]{2}{*}{$p$ value } & \multicolumn{2}{|c|}{$95.0 \%$ Confidence Interval for B } \\
\hline & & & Lower limit & Upper limit \\
\hline (constant) & 0.264 & 0.001 & 0.175 & 0.353 \\
\hline Age & 0.007 & 0.001 & 0.005 & 0.008 \\
\hline Gender & 0.060 & 0.004 & 0.020 & 0.100 \\
\hline Hyperlipidemia & 0.123 & 0.001 & 0.086 & 0.160 \\
\hline Smoking & 0.049 & 0.016 & 0.009 & 0.089 \\
\hline CVD & 0.082 & 0.004 & 0.027 & 0.136 \\
\hline CAD & -0.068 & 0.039 & -0.132 & -0.003 \\
\hline HT & 0.137 & 0.001 & 0.097 & 0.177 \\
\hline DM & 0.028 & 0.258 & 0.026 & 0.135 \\
\hline
\end{tabular}

CVD: Cerebro vasculary disease, CAD: Coronary artery disease, HT: Hypertension, DM: Diabetes Mellitus, 
age (0.007; 95\% CI: 0.005-0.008). CCA IMT values were significantly higher in the cases with plaque and/ or stenosis $(\mathrm{p}<0.01)$.

\section{Discussion}

Atherosclerosis is a diffuse disease involving various parts of the arterial system ${ }^{23}$. Epidemiological studies indicate many factors contributing to the development and progression of atherosclerosis. In addition to unchangeable risk factors such as genetic susceptibility, local arterial and hemodynamic factors and gender, modifiable risk factors such as HT, hypercholesterolemia, smoking, glucose intolerance, obesity and sedentary life style as well contribute to the development of atherosclerosis ${ }^{21}$. Increased carotid IMT is the earliest morphological sign of atherosclerosis ${ }^{2}$. Typically, atherosclerosis most commonly evolves on posterolateral wall of the bulb and then spreads all around ${ }^{24}$.

Histological studies revealed that media and adventitia thicknesses on ultrasound images are quite close to their real thicknesses ${ }^{25}$. Whilst internal hyperechogenic line represents the lumen-intima interface, external hyper-echogenic line represents the mediaadventitia interface and the distance between two lines indicates IMT. Thickness increases with age ${ }^{26}$. In addition to the change with age, IMT also increases with earlier plaque formation; therefore, IMT measurement is used as the sign of cardiovascular risk in many clinical settings ${ }^{27}$ and the carotid IMT is a strong predictor of cardiovascular events such as MI and stroke. In addition, increased carotid IMT is associated with HT, hyperlipidemia and cardiovascular diseases ${ }^{28,29}$. There are studies suggesting that individuals under risk for atherosclerotic diseases can be determined by measuring carotid IMT in young people and children ${ }^{30}$.

Age is among unchangeable factors that contribute to the development and progression of atherosclerosis ${ }^{21}$ and the positive correlation between age and carotid atherosclerosis is increasingly being emphasized ${ }^{6-8}$. Consistent with the literature, the present study demonstrated that IMT increased with age.

Atherosclerosis is several times more prevalent in young and middle-aged males versus females. It is suggested that male sex hormones are atherosclerogenic or female sex hormones are protective ${ }^{1}$. The facts that $\mathrm{CAD}$ is less prevalent among premenopausal females, symptoms appear meanly 10 years earlier in females versus males and the risk of disease increases with menopausal state confirm this hypothesis ${ }^{21,31}$. As was determined in the present study, the literature comprises the studies that reveal positive correlation between male gender and carotid $\mathrm{IMT}^{7,10,11}$. However, there are studies suggesting that gender has no effect on carotid IMT. Ertan et al. stated that gender does not influence carotid IMT and they attributed this to the female participants' being in the postmenopausal state?

Smoking is a modifiable risk factor ${ }^{21,32}$. In recent years, combating smoking has become one of the main goals of public health units in the USA and United Kingdom $^{33}$. In the present study, we as well found significant relation between carotid IMT and active smoking. Besides, there are studies in the literature stating that smoking does not influence carotid IMT $^{7,19}$. In their study, Oren et al. stated that smoking does not influence carotid IMT and they related with their sample characteristics consisting of young participants aged $27-30$ years $^{19}$.

HT is defined as one of the well-known atherosclerotic risk factors ${ }^{21}$. Prospective studies demonstrated that high blood pressure was associated with increased risk of atherosclerotic cardiovascular disease ${ }^{34,35}$. Regression analysis performed in the present study revealed that HT had the most important effect on carotid IMT, as reported previously $y^{7,12,13,36}$. However, some studies suggested that HT did not increase carotid $\mathrm{IMT}^{14}$. Fabris et al. propounded that HT influenced intracranial arteries rather than extra-cranial arteries ${ }^{37}$.

In the present study, we found that carotid IMT was statistically significantly higher in patients with histories of CVD and CAD. Consistent with our study, relation between carotid IMT and hyperlipidemia, CVD and CAD was documented previously ${ }^{4-6,8,38}$.

In addition to the researchers in the literature stating that DM increases carotid IMT, there are also researchers reporting no relation ${ }^{7,15,16,39,40}$. In the present study, univariate analyses demonstrated that DM is among the risk factors effective on carotid IMT; whereas, regression analysis revealed no significant effect of DM on carotid IMT. We think this outcome emerges from the fact that substantial proportion of DM participants in the present study consists of individuals with good glycemic control. Studies have put forward that good glycemic control decreased complications of DM. It was emphasized that an increase in $\mathrm{HbA} 1 \mathrm{C}$ by $1 \%$ provided $14 \%$ decrease in $\mathrm{MI}$ and $37 \%$ decrease in DM-related microvascular complications ${ }^{41}$. 
Various previous studies have mentioned about the relation between the presence and severity of plaque in carotid arteries and IMT ${ }^{7,42}$. In our study, the carotid IMT was significantly higher in the cases with plaque detected in the extra cranial ICA and CCA. Moreover, we observed that carotid IMT was statistically higher in the cases with a $15 \%$ or higher stenosis.

In conclusion, un-modifiable risk factors such as age and gender, as well as modifiable risk factors such as active smoking, HT, hyperlipidemia, CVD and CAD, increase carotid IMT.

\section{References}

1. Arthur C. Guyton, John E. Hall, Text Book of Medical Physılogy. Tıbbi Fizyoloji. Çeviri editörü; H. Çavuşoğlu 1. Basım 9. Edisyon 1996;873-5.

2. Seçil M. Temel Ultrasonografi ve Doppler 1 2008;479-98.

3. Glagov S, Weisenberg E, Zarins CK, et al. Compensatory enlargement of human atherosclerotic coronary arteries. N Engl J Med 1987;317:1604.

4. Stein JH, Korcarz CE, Hurst RT, et al. ASE Consensus Statement. Use of carotid ultrasound to identify subclinical vascular disease and evaluate cardiovascular disease risk: a consensus statement from the American Society of Echocardiography. Carotid Intima Media Thickness Task Force endorsed by the Society of Vascular Medicine. J Am Soc Echocardiogr 2008;21:93-111.

5. Bots ML, Hoes AW, Koudstaal PJ, et al. Common carotid intima-media thickness and risk of stroke and myocardial infarction: the Rotterdam Study. Circulation 1997;96:1432-7.

6. Daniel H. O'Leary, Joseph F. et al. Carotid-artery intima and media thickness as a risk factor for myocardial infarction and stroke in older adults. For the Cardiovascular Health Study Collaborative Research Group. N Engl J Med 1999;340:14-22.

7. Baroncini L, de Oliveria A, Vidal E, et al. Appropriateness of carotid plaque and intima-media thickness assessment in routine clinical practice. Cardiovasc Ultrasound 2008;6:52. doi:10 1186/1476-7120-6-52.

8. Chambless LE, Heiss G, Folsom AR, et al. Association of coronary heart disease incidence with carotid arterial wall thickness and major risk factors: the atherosclerosis risk in communities (ARIC) study, 1987-1993. Am J Epidemiol 1997;146:483-94.

9. Ertan NS, Karşıdağ S, Duran C et al. Karotis aterosklerozu gelişmesinde etkili risk faktörleri. Uludağ Üniversitesi Tip Fakültesi Dergisi 2003;29:19-24.

10. Kablak-Ziembicka A, Przewlocki T, Tracz W, et al. . Gender differences in carotid intima-media thickness in patients with suspected coronary artery disease. Am J Cardiol 2005;96:1217-22.
11. Paul J, Shaw K, Dasgupta S, et al. Measurement of intima media thickness of carotid artery by B-mode ultrasound in healthy people of India and Bangladesh, and relation of age and sex with carotid artery intima media thickness: An observational study. J Cardiovasc Dis Res 2012;3:128-31.

12. Lakka TA, Salonen R, Kaplan GA, et al. Blood pressure and the progression of carotid atherosclerosis in middle-aged men. Hypertension 1999;34:51-6.

13. Puato $M$, Palatini $P, Z$ anardo $M$, et al. Increase in carotid intimamedia thickness in grade I hypertensive subjects. Hypertension 2008;51:1300-5.

14. Lemne C, Jogestrand T, de Faire U. Carotid intima-media thickness and plaque in borderline hypertension. Stroke 1995;26:34-9.

15. Wagenknecht LE, D’Agostino R Jr, et al. Duration of diabetes and carotid wall thickness: the insulin resistance atherosclerosis study (IRAS). Stroke 1997;28:999-1005.

16. Dempsey RJ, Moore RW. Amount of independently predicts carotid artery atherosclerosis severity. Stroke 1992;23:693-6.

17. Johnson HM, Douglas PS, Srinivasan SR, et al. Predictors of carotid intima-media thickness progression in young adults: the Bogalusa Heart Study. Stroke 2007;38:900-5.

18. McMahan CA, Gidding SS, Viikari JS, et al. Association of pathobiologic determinants of atherosclerosis in youth risk score and 15-year change in risk score artery intima-media thickness in young adults. Am J Cardiol 2007;100:1124-9.

19. Oren A, Vos LE, Uiterwaal CS, et al. Cardiovascular risk factors and increased carotid intima-media thickness in healthy young adults: the Atherosclerosis Risk in Young Adults (ARYA) Study. Arch Intern Med 2003;163:1787-92.

20. Touboul PJ, Hennerici MG, Meairs S, et al. Mannheim intimamedia thickness consensus. Cerebrovasc Dis 2004;18:346-9.

21. Andreloi TE, Bennet C, Carpenter C, et al. Cecil Essentials of Medicine. Çeviri editörü: Tuzcu M, Çalangu S, Sıva S 2000;53-5.

22. North American Symtomatic Carotid Endarterectomy Trial Collaborators: NASCET Beneficial effect of carotid endarterectomy in symptomatic patients with high-grade carotid stenosis. N Engl J Med 1991;325:445-53.

23. Zivibel WJ, Pellerito JS, MD. Introduction to vascular ultrasonography. Vasküler Ultrasona Giriş. Çeviri Editörü: İsmail Mihmanlı 1. Baskı 2006;142-69.

24. Katz DS, Math KR, . Groskin SA. Radiology Secrets. Radyoloji Sırları. Çeviri editörleri: Oğuz M, Aksungur E, Bıçakçı K, ve ark 2001;487-94.

25. Wolverson MK, Bashiti HM, Peterson GJ. Ultrasonic tissue characterization of atheromatous plaques using a high resolution real time scanner. Ultrasound Med Biol 1983;6:669-709.

26. Sidhu PS, Chong WK. Measurements in ultrasound. Ultrasonda ölçümler. Çeviri editörleri: Özel A, Ertürk ŞM 2008; 222-9.

27. Sun Y, Lin CH, Lu CJ, et al. Carotid atherosclerosis, intima media thickness and risk factors an analysis of 1781 asymptomatic subjects in Taiwan. Atherosclerosis 2002;164:89-94. 
28. European Society of Hypertension-European Society of Cardiology Guidelines Committee 2003 European Society of Hypertension- European Society of Cardiology guidelines for the management of arterial hypertension. J Hypertens 2003;21:1011-53.

29. Hedblad B, Wikstrand J, Janzon L, et al. Low-dose metoprolol $\mathrm{CR} / \mathrm{XL}$ and fluvastatin slow progression of carotid intima media thickness: main results from the Beta- Blocker CholesterolLowering Asymptomatic Plaque Study (BCAPS). Circulation 2001;103:1721-6.

30. Barth JD. An update on carotid ultrasound measurement of intima-media thickness. Am J Cardiol 2002;89:32-8.

31. Jansen SC, Temme EH, Schouten EG. Lifetime estrogen exposure versus age at menopause as mortality predictor. Maturitas 2002;43:105-12.

32. O'Brien DK. The biology of the artery wall in atherogenesis. Med Clin N Am 1994;78:41-67.

33. A Clinical Practice Guideline for Treating Tobacco Use and Dependence. A US Public Health Service Report. The Tobacco Use and Dependence Clinical Practice Guideline Panel, Staff, and Consortium Representatives. JAMA 2000;283:3244-54.

34. Stamler J, Stamler R, Neaton JD. Blood pressure, systolic and diastolic, and cardiovascular risk. Arch Intern Med 1993;153:598-615.
35. Kannel WB. Blood pressure as a cardiovascular risk factor: prevention and treatment. JAMA 1996;275:1571-6.

36. Sorof JM, Alexandroy AV, Cardwell G, et al. Carotid artery IMT and $\mathrm{LVH}$ in children with elevated blood pressure. Pediatrics 2003;111:61-6.

37. Fabris F, Zanocchi M, Bo M, et al. Carotid plaque, aging and risk factors: A study of 457 subjects. Stroke 1994;25:1133-40.

38. Lorenz MW, Von Kegler S, Steinmetz H, et al. Carotid intimamedia thickening indicates a higher vascular risk across a wide age range: prospective data from the Carotid Atherosclerosis Progression Study (CAPS). Stroke 2006;37:87-92.

39. Mohan V, Ravikumar R, Shanthi Rani $S$, et al. Intimal medial thickness of the carotid artery in South Indian diabetic and non-diabetic subjects: The Chennai Urban Populations Study (CUPS). Diabetologia 2000;43:494-9.

40. Rodrigo RR, Gomez-Dias RA, Haj JT, et al. Carotid intimamedia thickness in pediatric type 1 diabetic patients. Diabetes Care 2007;30:2602-7.

41. Saaddine JB, Cadwell B, Gregg EW et al. Improvements in diabetes processes of care and intermediate outcomes: United States 1988-2002. Ann Intern Med 2006;144:465-74.

42. Persson J, Formgren J, Israelsson B, et al. Ultrasound-determined intima-media thickness and atherosclerosis: direct and indirect validation. Arterioscler Thromb 1994;14:261-4. 